\title{
Ardıl çeviri eğitiminde dikkat yönetimi ve çalışma belleği dinamikleri
}

\section{Alev YEMENICI'1} APA: Yemenici, A. (2019). Ardıl çeviri eğitiminde dikkat yönetimi ve çalışma belleği dinamikleri.
RumeliDE Dil ve Edebiyat Araştırmaları Dergisi, (Ö5), 297-313. DOI: 10.2900o/rumelide.606163

\section{$\ddot{O} \mathbf{z}$}

Ardıl çeviri, çevirmenin yukarıdan-aşağıya dikkatini, aşağıdan-yukarıya dikkatini, dinlenme durumu ağlarını ve çalışma belleğini yetkin biçimde yönetmesini gerektiren son derece zorlayıcı bir süreçtir. Çalışma belleğine bilginin girmesi ve işlenmesi ancak yukarıdan-aşağıya dikkatinin odaklanması sonucu gerçekleşir. Bilginin işlenmesi sürecinde, çevirmenin kulağına gelen bilginin tanınması, çözümlenmesi ve anlamlandırılması üzerine çevirmen konuşmaya ilişkin bir kavrayış elde eder. Çevirmen yukarıdan-aşağıya dikkatini konuşmaya odaklanmak amacıyla korumaya çalışırken belleği olumsuz yönde etkileyebilecek dinlenme durumu ağlarını ve aşağıdan-yukarıya dikkatini de denetlemek durumundadır. Ancak bu şekilde çalışma belleğine girecek bilgi işlenerek artalan bilgisiyle bütünleştirileceğinden akıcı ve güvenilir bir çeviri yapılabilir. Bu makalede, sözlü çeviride yetkinlik noktasına ulaşabilmek için bilinmesi gereken bellek dinamikleri ve dikkat türleri üzerinde durulmakta, hem bilginin kodlanması hem de geri çağrılmasında çevirmenin işini kolaylaştıracak stratejilere değinilmekte, ayrıca ardıl çeviri sırasında ortaya çıkabilecek beklenmedik sorunlara bağlı olarak yaşanabilecek dikkat kaybının engellenmesine yönelik öneriler üzerinde durulmaktadır. Bu makalede dikkat ve bellek yönetiminin yanında ardıl çeviri eğitiminde önemli yer tutan ve hem bellek işleyişini hem de dikkat sistemlerini yöneten yürütücü biliş, stres ve sorunlarla başa çıkma stratejilerine de yer verilmiştir.

Anahtar kelimeler: Ardıl çeviri öğretimi, yukarıdan-aşağıya dikkati, aşağıdan-yukarıya dikkati, dinlenme durumu ağları, bellek yapıları.

\section{Management of attention and dynamics of working memory in consecutive interpreting training}

\begin{abstract}
The process of consecutive interpreting is an extremely challenging process that requires the interpreter to control and manage her top-down attention, bottom-up attention, default-mode network along with the working memory so that information can enter the working memory to be processed effectively. Thus, the interpreter perceives the speech while the information is being analyzed and recognized in the brain and comes to an understanding of what it means. While making every effort to control her top-down processing to focus only on the speech, the interpreter has to manage her default-mode network and bottom-up attention so that these two types of attention would not negatively affect her verbal output. Only then can the incoming information enter the working memory to be processed and integrated with the interpreter's prior knowledge, which leads to fluent and reliable translation of the speech. Main points of focus in this article are dynamics of memory and attention, with strategies that help the interpreter encode and retrieve information, and
\end{abstract}

1 Dr. Öğr. Üyesi, Cankaya Üniversitesi, Edebiyat Fakültesi, Mütercim-Tercümanlık Bölümü (Ankara, Türkiye), alevyemenici@gmail.com, ORCID ID: oooo-0002-1379-4327 [Makale kayit tarihi: 12.06.2019-kabul tarihi: 18.08.2019; DOI: $10.29000 /$ rumelide.606163] 
suggestions that will assist the interpreter to avoid/manage loss of attention that may result from unexpected problems. Within the context of the dynamics of memory and attention and how to manage them, factors such as stress, strategies to cope with problems, and metacognitive awareness, which is essential in the management of memory systems and attention, are also examined.

Keywords: Consecutive interpreting training, top-down attention, bottom-up attention, defaultmode processing, memory systems.

\section{Giriş}

Sözlü çeviri süreci, söz konusu olan ister andaş çeviri ister ardıl çeviri olsun, özellikle dikkat ve bellek dinamikleri göz önünde tutulduğunda, sözlü çeviriyi yapan kişiyi son derece zorlayan bir süreçtir. Çevirmenin akıcı ve doğru bir çeviri yapabilmesi, ortaya çıkabilecek sorunlarla baş edebilmesi için özel bir donanıma ve yetkinliğe sahip olması gereklidir. Bu da ardıl çeviri eğitimi sırasında süreci etkileyen unsurların işleyiş dinamiklerinin bilinmesini ve bu dinamiklerin yönetilmesini zorunlu kllar.

Ardıl çeviri yapan çevirmen bir yandan konuşmacıyı uzunca bir zaman dinleyip not tutar, bir yandan da dinlediklerini anlamlı ve anlaşılabilir bir söylem örüntüsü içinde hedef dilde akıcı biçimde ifade etmeye çalışır. Çevirmen kaynak dilde verilen bilgiyi öncelikle tam olarak anlamalı, konuşmacının mantık çizgisini izleyebilmeli, konuşmanın gidişini büyük ölçüde ve doğru olarak kestirebilmeli, sembollerin ve kısaltmaların yardımıyla not defterine aktarmalı, verilen bilginin ana hatlarını ve gerekli ayrıntıları doğru, neredeyse eksiksiz olacak şekilde aktarmalıdır. Bu dinamik süreçte, sahip olduğu bellek kapasitesi ve bu kapasiteden kısıtlı bir zaman dilimi içinde hızlı bir şekilde yararlanabilmesi büyük önem taşır. Çevirmen adayının özellikle eğitimi süresince çalışma belleğinin işleyişini ve sınırlılıklarını anlaması, bu doğrultuda bilginin bozulmadan bellekte tutulabilmesi için yapılması gerekenleri bilmesi, süreci destekleyici ve köstekleyici unsurları tanıması; çeviri sürecinde ortaya çıkacak olan engelleri ve çalışma belleğinin sınırlılıklarını aşmasını sağlar. Eğitimi süresince çalışma belleğinin sınırlarını genişletecek uygulamaları tanıması ve farkındalıkla yapması, çalışma belleğinin performansını destekler. Ancak bunun sonucunda doğru, güvenilir ve yetkin bir çeviri ortaya çıabilir.

Bu makalede, özellikle ardıl çeviri eğitimi sürecinde öne çıkan ve kısa süreli bellek kapsamında yer alan çalışma belleğini destekleyen "yürütücü biliş" ve "yukarıdan-aşağıya dikkati" ile çalışma belleğini ve duyusal belleği olumsuz yönde etkileyen "stres," "aşağıdan-yukarıya dikkati" ve "dinlenme durumu ağları" olmak üzere sözlü çeviride kaliteyi belirleyen önemli unsurlara değinilecektir. Ayrıca bu unsurlardan ardıl çeviri sürecinde hızlı, doğru ve güvenilir bir çeviri yapılmasını sağlayacak şekilde yararlanabilmenin yolları irdelenecektir. Bu çerçevede çeşitli etkili öğrenme, çalışma ve uygulama yöntemleri ele alınacaktır. Bu unsurlar, özellikle çeviri eğitimi almakta olan ya da yeni mezun olmuş, yani deneyimi sınırlı çevirmen adayları için etik açıdan büyük önem taşımaktadır. Çünkü çalışma belleğinin sınırlılıkları nedeniyle çalışma belleğinden uzun süreli belleğe bilgi aktarımı sırasında önemli ölçüde bilgi kaybı yaşanabilmektedir. Bilginin sistemli biçimde kodlanamaması sonucunda uzun süreli bellekten bilginin çağrılması sırasında doğan boşluklar, dikkat kaybı ve çeviri yapılacak farklı alanlara ilişkin artalan bilgisindeki eksiklikler nedeniyle alana henüz adım atmakta olan çevirmen adayının ${ }^{2}$ duyduğunu doğru olarak anlayamaması, söylenenleri anlamlandıramaması ya da doğru biçimde aktaramaması söz konusu olabilmektedir. Bu noktada bu durumun, erek ve kaynak dillerin

\footnotetext{
$2 \quad \mathrm{Bu}$ çalışma özellikle ardıl çeviri alanında çalışmak isteyen çevirmen adaylarının içinde bulunduğu sürece ilişkin farkındalık yaratmak ve adaylara yetkinlik kazandırmak üzere kaleme alınmıştır. Bu nedenle metnin akıcılığını sağlamak adına metnin geri kalanında "çevirmen adayları" yerine "çevirmen" ifadesi kullanılmıştır.
} 
kullanımında yetkin, kültürel açıdan donanımlı çevirmenler için de söz konusu olduğunu vurgulayalım, çünkü ardıl çevirinin doğası gereği, çevirmen konuşmaya tam olarak odaklanamazsa belirgin ölçüde anlama ve kavrama sorunu yaşayacaktır. Buna ek olarak, çeşitli aksaklıklar sonucu çevirmenin duyduklarını doğru olarak ifade etmesini sağlayacak şekilde hızlı ve doğru not tutamaması da hedef dile aktarım sırasında yanlışlara ya da anlamın çarpıtılmasına yol açabilir. Bu durum çevirmeni mesleki anlamda zor duruma sokar ve uzun vadede mesleğine yönelik motivasyonunu, kendine ve alana yönelik güvenini yitirmesine yol açabilir. Bir çevirmenin mesleğinde kendini denetleyebilmesi, kendini yaratıcı biçimde ifade edebiliyor olması, güvenilir, akıcı ve yetkin çeviri yapabilmesi bir taraftan duygusal olarak gelecekteki deneyimlere onu hazırlarken bir taraftan da özgüveninin gelişmesini sağlayacaktır.

\section{Ardıl çevirinin aşamaları}

Ardıl çevirinin dinamik ve zorlayıcı bir süreç olduğu gerçeğinden yola çıkarak çevirmenin içinden geçtiği aşamalara bakacak olursak, çeviri sürecinin tam dikkat ve denetim gerektiren üç basamaktan oluştuğunu görürüz. Çevirmenin öncelikle konuşmacının söylediklerine tam olarak odaklanabilmesi; söylenenleri vurgusuyla, taşıdığı duyguyla ve konuşmacının aktarmak istediği iletiyi bütünlüğü içinde tam olarak anlaması ve değerlendirebilmesi gerekir. Ardıl çevirinin bu evresi, çevirmenin bilgiyi dil yoluyla alıp zihnine yerleştirdiği "kavrama ve algllama" evresidir. İkinci basamak çevirmenin anladıklarını çözümleyerek kendine özgü sembol ve kısaltmalardan oluşan notlar olarak kâğıda geçirmesini içerir. Üçüncü basamağa geldiğinde çevirmen, almış olduğu notlardan yararlanarak konuşmacının ifade ettiği fikirleri zihninde yeniden düzenleyerek (Doğan, 2011, s. 150) konuşmacının vurgularını, ileti bütünlüğünü, fikirlerin özünü, örnek ve ayrıntılar eşliğinde, içerdiği duygusal renkleri koruyarak akıcı biçimde hedef dilde ifade etmelidir. İkinci ve üçüncü basamaklar, ardıl çeviri sürecinin ikinci evresi olan "üretim" evresini oluşturur. Birinci ve ikinci basamaklar iç içe olsa da bu çalışmada, sözü edilen dinamikleri tanımlayabilmek adına ayrı basamaklar olarak ele alınmıştır. Sembol ve kısaltmalardan oluşan notlar bire bir anlam ifade etmediğinden ve notlar sadece çözümlenerek kavramlara dönüştürülmüş fikirlere karşlılk geldiğinden çevirmen, kaynak dilde ifade edilen fikirleri kendi yaratıcı sürecinden geçirerek yeniden sentezlemek durumundadır. Bir yandan da ardıl çeviri yaparken yürütücü bilişini kullanarak kendini izlemeli ve hatalarını, eksiklerini gözleyerek en uygun zamanda gereken düzeltmeleri ya da eklemeleri yapmalıdır.

Birçok işin aynı anda başarılmasını gerektiren ardıl çeviri sırasında çevirmenin tüm süreci başarıyla yönetebilmek için çeviriyi doğru ve akıcı biçimde yapmasını sağlayacak şekilde bellek kapasitesini kullanabiliyor, dikkatini denetleyebiliyor olması gerekir. Gile'ye göre, çevirmenin çalışma belleği kapasitesinin sınırlı oluşu onu bellek çabası içine sokmaktadır. Bu nedenle bellek performansının, yapılacak çevirinin gerektirdiği bellek kapasitesiyle uyumlu olması bir ön koşuldur (Gile, 1995). Konuşmanın hızlı bir akış içinde olması, çevirmenin tüm konuşma boyunca dikkatini konuşmacıya odaklamak durumunda olması ve bu yöndeki yoğun çaba, kaynak dilde bilinmeyen sözcüklerin ya da yabancı kavramların yer alması, konunun çevirmene yabancı olması, hedef dile aktarım sırasında çevirmenin yaşayabileceği ifade bozuklukları nedeniyle çeviriyi düzeltme çabası ve yürütücü bilişi yöneterek çeviriyi sürekli olarak denetlemek gibi unsurlar bellek kapasitesini zorlayıcı unsurlardır (Doğan, 2011, s. 155).

Çevirmenin bellek türleri, işlevleri ve bellek-dikkat ilişkisi konularında bilgi sahibi olması, belleğini geliştirmeye ve dikkatini odaklamaya yönelik uygulamalar yapması, çeviri sürecinde çevirmenin dikkatini yönetebilmesini ve doğruluk değeri yüksek, kaliteli çeviri yapabilmesini sağlar. Sadece ana dil ve yabancı dil (erek dil ve kaynak dil) bilgisine sahip olmak mütercim-tercümanlık mesleğinde varlık 
gösterebilmek için yeterli değildir. Ayrıca ülkemizde çeviri eğitimi almakta olan öğrencilerin sahip olması gereken temel dil becerilerinin tam olarak gelişmiyor olması da söz konusudur. Gazi Üniversitesi Eğitim Fakültesi, Fransız Dili Eğitimi Anabilim Dalındaki çeviri öğrencileri üstünde yapılmış olan bir araştırmada (Yalçın, 2003), çeviri sınavlarında başarısız olan öğrencilerin çoğunun ana dillerinde ve yabancı dilde yetersiz oldukları görülmüştür. Bu da öğrencilerin metinleri ya da konuşmaları doğru olarak çözümleyebilmelerini ve akıcı bir çeviri yapmalarını engellemektedir. Ayrıca dinleyicilerin ya da okuyucuların üzerinde etki yaratacak güçte özgün konuşmanın taşıdığı anlamı ve ifade etmek istediği iletiyi doğru olarak aktarmalarını sağlayacak dilsel donanıma sahip olmadıkları anlamına da gelmektedir. Mütercim-tercümanlık mesleğinde uzmanlaşmaya kararlı olan öğrencilerin, sadece duyduklarını anlayacak kadar dil bilmeleri yeterli değildir. Bu mesleğin gereklerini hakkıyla yerine getirebilmek için hem kaynak dili hem de erek dili çok iyi düzeyde bilmenin ve akıcı biçimde konuşabilmenin yanı sıra çevirmenin şu yetkinliklere de sahip olması gerekmektedir:

a. Kendi toplumunu ve kültürünü tanımak, tarihini bilmek ve güncel gelişmeleri izlemek,

b. Sahip olduğu bir ya da daha fazla yabancı dilin konuşulduğu toplumları ve kültürlerini tanımak, tarihlerini bilmek ve güncel gelişmeleri izlemek,

c. Kıvrak bir zekaya sahip olmak ve çeviri sürecinde farklı nedenlerle ortaya çıkabilecek sorunları hemen çözüme kavuşturabilmek,

d. Sorunlar karşısında yapıcı olmak ve yaratıcı çözümlere başvurabilmek,

e. Sözlü çeviri aşamalarını, bu aşamaların gereklerini ve dinamiklerini anlamak,

f. Farklı alanlarda derin ve kapsamlı artalan bilgisine sahip olmak,

g. Sözlü çevirinin farklı aşamalarında farklı stratejiler kullanabilmek ve kestirim yapabilmek,

h. Zaman baskısı altında verimli çalışabilmek,

i. Stres yönetiminde deneyim kazanmış olmak,

j. Sözlü çeviri sırasında bellek kapasitesini yönetebilmek ve dikkatini uzun süreli olarak odaklayabilmek,

k. Güncel bir dil kullanarak akıcı, tutarlı ve doğru çeviri yapmak,

1. Çeviri üzerinde denetim kurabilmek, eksik ve hataları saptayıp düzeltebilmek için yürütücü bilişi geliştirmiş olmak.

Bir çevirmen sadece erek ve hedef dillerin kullanımında değil, yukarıda belirtilen noktalarda da yetkinlik kazandığında ancak dilden dile, kültürden kültüre kaliteli bir çeviri yapabilir. Ardıl çevirinin üç temel basamağının birbiriyle etkileşimi sırasında çevirmeni desteklemesi gereken çalışma belleğinin kapasitesi, bu bellek türünün işleyiş dinamikleri bilinmediğinde, son derece sınırlıdır. Bu nedenle çalışma belleği en önemli anlarda çevirmeni yarı yolda bırakabilir. Bu konuya ışık tutabilmek amacıyla belleğin işleyiş dinamikleri ile duyusal belleğin, kısa süreli belleğin ve çalışma belleğinin sözlü çevirideki yerini, belleğin farklı dikkat türleriyle etkileşimi, stres yönetimi ve yürütücü biliş kapsamında ele alalım.

\section{Bellek türleri ve dikkat}

\section{Duyusal bellek ve stres}

Araştırmacılar, üstlendiği işlevlere bağlı olarak belleği farklı türlere ayırarak incelemektedirler. Ele alacağımız ilk bellek türü “duyusal bellek”tir. Duyular yoluyla eşzamanlı olarak çevreden beyne gelen çok sayıdaki uyaran, beyinde uyaranlara bağlı olarak oluşan sinir hücre örüntülerinde çok kısa bir süre boyunca saklanır. Uyaranlar, işe yarayabilirliklerine göre beyinde bir süzgeçten geçirilir (Broadbent, 1958), işe yaramayan uyaranlar süzülür. Böylece yoğun uyaran akışı nedeniyle kişiyi etkisiz hale getirme 
riski taşıyan birçok uyaran farkındalığa ulaşmaz ve kaybolup gider. Kapasitesi sınırsız olan duyusal bellek düzeneği (Treisman, 1964), gereksiz gördüğü uyaranları tamamen reddetmez, ancak sesini kısar (Treisman, 1964). Sesi kıslan uyaranlar ise farkında olmadığımız uyaranlardır. Broadbent'e (1958) göre, filtrede takılmayıp farkındalığa ulaşan uyaranlar, artalan bilgisiyle uyumlu uyaranlardır. Böylelikle uyaranlar duyularla algılanmaya başladığında biz de onların ne anlama geldiğini çözümleyebiliriz. Artalan bilgisiyle uyumlu olan uyaranlar, artalan bilgisiyle bütünleştiğinde bize anlamlı gelen ve bu çerçevede dikkatimizi yöneterek anlamlı bilgiyi anlamsız ya da gereksiz bilgilerden ayırt etmemizi sağlayan uyaranlardır. Bu ayrıştırma otomatik olarak gerçekleşir (Morris ve Maisto, 2002). Bir sonraki adımda ise bize anlamlı gelen ve önemli olan bilgiyi seçerek akılda kalacak şekilde işlemeye başlarız.

Beynin gelmekte olan uyaranları süzme sürecinde etkili olan bazı unsurlar vardır. Duyulardan gelen bilginin süzülmesi doğal olarak beynin hayatta kalma programı tarafından belirlenir. Bir başka deyişle, tanıdık olmayan, alışılmışın dışında olan ve bu nedenle hayatta kalma programı açısından tehlike biçiminde algılanan uyaranlar öncelikli olarak farkındalığa sunulur.

Bu çerçevede hayatta kalma programı duyularla algıladığımız uyaranların, özellikle görme ve duyma yoluyla algıladığımız uyaranların çok kısa bir süre boyunca kısa süreli bellek yolaklarında kalmasına izin verir. Söz gelimi görme duyusuyla algılanan uyaranlar duyusal bellekte sadece saniyenin dörtte biri gibi kısa bir süre tutulur (Morris ve Maisto, 2002) ve yerini gelmekte olan yeni bilgiye bırakır. İşitsel bilgi ise duyusal bellekte sadece birkaç saniyeliğine tutulur (Morris ve Maisto, 2002). Bir başka deyişle, bulunduğu çevrede kişinin güvenliğini tehdit edebilecek unsurlara karşı hazırlıklı olması ve ortaya her an çıkabilecek değişimlerin farkında olarak güvenliğini sağlaması yolunda evrimleşmiş olan bellek düzeneği, milisaniyeler içinde kendini güncelleme becerisi geliştirmiştir.

Bu çerçevede bakıldığında, yeni ve farklı olan, hareket eden ya da aniden ortaya çıkan uyaranların dikkat çektiği, ama sıradan olanın fark edilmediği görülür (Jensen 2000). Hayatta kalmaya odaklı işleyen bu dikkat türüne "aşağıdan-yukarıya dikkati" adı verilmektedir (Madigan, 2015).

Evrimsel süreçte ilkel atalarımızın beklenmedik şekilde yırtıcıların avı olmamaları amacıyla evrimleşmiş olan aşağıdan-yukarıya dikkati yoluyla dış dünyadaki uyaranlar dikkatimizi çeker. Böylece dikkatimiz meşgul olduğumuz işten kayıp dış dünyadaki uyaranlara yönelir. Söz gelimi internette bir haber okurken ya da araştırma yaparken birdenbire karşımıza çıkan reklamların hemen farkına varmamız bu dikkat düzeneği tarafından sağlanır. Sözlü çeviri sırasında ise salonda duyulan beklenmedik bir ses ya da ani bir hareket bu nedenle çevirmenin tüm dikkatini kolayca dağıtabilir.

Bilginin beyinde süzülmeyip kalıcı olmasını belirleyen önemli bir başka unsur da duygulardır. Beyin evrim sürecinde, yine hayatta kalma programı çerçevesinde, duyguların gerektiğinde düşüncelerin akışını durdurmasını ve korku gibi güçlü bir duygu sonucunda tetiklenen "savaş ya da kaç" tepkisiyle kişinin hızla harekete geçerek kendini tehlikeden kurtarmasını sağlamak üzere uyaran akışının çok hızlı işlediği bilgi otoyolları kurmuştur. Böylece güçlü duygular, biz daha fark etmeden bizi yönetir. Duygular sempatik sinir sistemini harekete geçirir ve duygusal açıdan önemli bir deneyimin sonucunda salgılanan adrenalin güçlü anıların oluşmasını sağlar (Jensen, 1998, 2000). Ayrıca korku ve stresle ilişkili olarak hem böbrek üstü bezlerinde hem de beyinde salgılanan noradrenalin de uzun süreli ve kısa süreli kodlamaya yardımcı olur (Jensen, 2000). Olumlu duygular, heyecan ve belli oranda stres bilginin kodlanmasına katkı sağlar. Söz gelimi, aşırı olmamak koşuluyla, adrenalin duyuları keskinleştirir, dikkatin keskin biçimde odaklanmasını sağlar. Beyni uyararak çevreden hızla bilgi toplanmasını sağlar (Bremner, 2005). Kalp daha hızlı atacağından beyne giden oksijen ve besin miktarı da artar. 
Noradrenalin düzeylerindeki artış ise odağı güçlendirirken kişinin uyanık ve dinamik olmasını sağlar (Bremner, 2005). Hafif düzeyde stresle ilişkili olarak ortaya çıkan tüm bu fizyolojik değişimler sözlü çeviri sürecinde çevirmenin yetkin bir çeviri yapmasını destekler. Ancak bunun koşulu, çevirmenin "dinlenme durumu ağları"nı değil, hedefe odaklanmayı sağlayan "yukarıdan-aşağıya dikkati"ni kullanması (Madigan, 2015) ve odağını konuşmacıdan ayırmamasıdır (Roche, 1999).

Çevirmen, performansına ilişkin bir kaygı duyduğunda dikkati konuşmacıdan kayıp duygularına yönelir. Dikkatini, kaygıya bağlı olarak bedeninde ortaya çıkmakta olan strese dayalı değişimlere odaklarsa, artan kalp atışı ve yükselen kan basıncı nedeniyle paniğe kapılırsa, o zaman, "dinlenmedurumu ağları" dikkatini yönetmeye başlar. Bu dikkat sistemi, çevirmen kaygı duymaya başladığı anda devreye girer. Çalışma belleğinin, çevrilmesi gereken fikirlerle değil, kaygı içerikli düşüncelerle dolmasına yol açar; bir taraftan da çeviriyi yürütmesini sağlayacak yukarıdan-aşă̆ıya dikkatini engeller (Madigan, 2015). Bu durumda beyin hayatta kalmaya öncelik vermekte ve üst düzey bilişsel işlemleri askiya almaktadır (Jensen, 2000).

Kendini tehdit altında hisseden bir kişinin beyni dikkatini, tehdit algısıyla şekillenen duyguların işaret ettiği noktalara yöneltir. Böylece kişi, yoğun duyguları yaşamasına neden olan olay, durum ve insanlara odaklanır. Duyguların alarm zillerini çaldığı bir anda beyin, bedenin enerjisini bilişsel işlemlere değil, stres yaratan durumla baş etmek amacıyla savaş ya da kaç tepkisini başlatarak fizyolojik bir değişimi sağlamaya yönlendirecektir. Buna eşlik edecek şekilde stres hormonları salgılanacak, böylece kişinin gerekirse fiziksel bir mücadelede hayatta kalmasını sağlayacak şekilde bedensel dengeleri yeniden kurulacaktır. Bu sırada beyindeki kan akışı da yön değiştirir (Drevets ve Raichle, 1998). Eleştirel düşünme, yaratıcılık, çıkarım yapma ve kestirim gibi yüksek düzeyli bilişsel işlemlerden sorumlu olan "ön lobların üst bölgelerine değil de duygulardan sorumlu bölgelere" yönelen kan akışı; korku, kaygı ve çaresizlik gibi duyguların güçlenmesini destekler (Jensen, 2000, s. 238). Bu durumda beyin, çevrilmesi gereken konuşmanın ayrıntılı biçimde anlaşılmasını ve akıcı ve doğruluk değeri yüksek bir çeviri yapılmasını sağlayacak düzeneği askıya alır. "Savaş ya da kaç" tepkisine bağlı olarak çok miktarda salgılanan adrenalin, noradrenalin ve kortizol gibi stres hormonları nedeniyle yaratıcı düşünceleri ve fikirlerin düzenlenmesini yöneten, konuşmanın etkileyici biçimde hedef dile aktarılabilmesini sağlayan işlemlerin yönetildiği ön beyin loblarına kan akışı azalır (Jensen, 200o). Beyin, heyecan ve korku ile stres tepkisinin tetiklenmesi sonucu mücadele içine girerek hayatta kalmak üzere evrim geçirdiğinden dolayı korku ve kaygı ile ortaya çıkan tehdit algısı, bilişsel becerileri bu şekilde devre dışı bırakırken adrenalin salınımına bağlı olarak kalp atışını ve soluk alış-verişini hızlandırır. Karaciğerde ve kaslarda depolanmış olan glikoz, enerji üretmek üzere kullanılmaya başlar. Özellikle karaciğerde beynin yararlanması için depolanmış olan glikoz mücadeleye hazırlık amacıyla harcanır. Ortaya çıkan stres tepkisine bağlı olarak kaslar gerilir; böylelikle tehdit kaynağına karşı savaşmak ya da ondan kaçmak üzere kişi hazırlanır. Tam da bu anda çevirmenin en çok gereksindiği şey salondan kaçmak değil, bilişsel becerilerini kullanmaktır; ancak savaş ya da kaç tepkisi buna izin vermez.

Ardıl çeviri sırasında çevirmenin yoğun duygular yaşaması ve performansına ilişkin kaygılar duyması doğaldır. Ancak sorun çevirmenin dikkatini, hissettiği korkuya ve kaygılara yönlendirmesidir. Sözlü çeviri sırasında ortaya çıkabilecek sorunlara bağlı olarak stres tepkisi tetiklendiğinde çevirmen dikkatini hissettiği gerginliğe ve kaygılara odaklarsa, otomatik olarak harekete geçen bu hayatta kalma düzeneği nedeniyle akıcı, yaratıı, doğru ve etkili bir çeviri yapamaz. Çünkü bir yandan üst düzey bilişsel işlemler askıya alınırken bir yandan da konuşmacıya odaklanması gereken dikkatin yönü değişmektedir. Böylece hedefe odaklanmayı sağlayan yukarıdan-aşağıya dikkatinin yerini, çevirmenin hissetmeye başladığı korku ve kaygıya yönelik işleyen dinlenme durumu ağlarının desteklediği dikkat türü alır. Çevirmen 
kaygıya odaklanarak çeviri sürecinden uzaklaştığında korktuğu başına gelir ve "belleğinin kendisini yolda bıraktığını düşünür, ancak gerçek sorun yukarıdan-aşağıya dikkatinin devre dışı kalmış olmasıdır" (Madigan, 2015, s. 47). Dinlenme durumu ağları, çevirmenin dikkatini iç dünyasına yönelteceğinden konuşmayı kaçırmakta olduğunu fark etmesiyle birlikte çevirmen, daha da yoğun bir strese kapılarak kısır bir döngüye girebilir.

Bu noktada çevirmen stresini kontrol edemezse salgılanan stres kimyasallarına bağlı olarak aşırı sinirsel uyarılma nedeniyle gerginlik tepkisinde kalır. Stresini kontrol etmeyi öğrenmediğinde ve daha önce kaygıya yol açmış çeşitli olumsuz koşulların tekrar tekrar ortaya çıkabileceği varsayımıyla olumsuz bir deneyim beklentisi içine girdiğinde çevirmenin stres tepkisi zamanla kronik hale gelebilir. Kronik stresin bağışıklık sistemine ve beynin işleyiş düzeneklerine zarar verdiği bilinmektedir (Sapolsky, 2004). Önemli bir bellek yapısı olan hipokampüs, kronik strese bağlı olarak salgılanan kortizolün yüksek düzeylerinden olumsuz yönde etkilenir. Hem hücre yüzeyinde stres tepkisine öncelik tanıyacak biçimde değişimler ortaya çıkar hem de hipokampüs bölgesinde "hücre ölümü" gerçekleşir (Bremner, 2005, s. 268).

Stres hormonlarıyla hipokampüsün büyüklüğü ve işlevi arasındaki ilişkiyi araştıran bir çalışmada (Lupien ve araştırma grubu, 2002), kortizol hormonu yllarca yüksek düzeyde seyreden yaşlı kişilerin, kortizol düzeyi normal olan yaşlı kişilere oranla, hipokampüslerinde küçülme olduğu görülmüş, kitap bilgisini kodlayan ve anlam-odaklı işleyen bellek işlevlerinde bozulma saptanmıştır. Ayrıca uzun süreli stresin orta yaşlı farelerde hipokampüsün körelmesine ve bellek kaybına neden olduğu da vurgulanmaktadır. Hipokampüste görülen küçülme, bellek işlevlerinde zayıflamaya, unutkanlığa ve öğrenme sorunlarına yol açmaktadır. Vincent'e (1990) göre, kortizole bağlı olarak hipokampüste ortaya çıkan değişimin sonucunda kişiler düşünce karmaşası yaşayabilmektedirler; hipokampüsü küçülen bireyler önemli olan ve olmayan durumları birbirinden ayırmakta başarılı olamamaktadırlar. Bir başka deyişle, bir çevirmen uzun süreli olarak kontrol edemediği bir stres içinde işini sürdürdüğünde belleğinde belirgin bir zayıflama görülecek, buna bağlı olarak da çeviri sırasında duyduğu konuşmanın ana hatlarını yan fikirlerden ayırmakta, önemli ve önemsiz ayrıntıları birbirinden ayırt etmekte zorluk çekecektir. Lupien ve araştırma grubu (2002), belli bir düzeyde stres kimyasallarının gerekli olduğunu, bu kimyasalların duygularla ilişkili olan ya da olmayan farklı bellek düzeneklerinin işleyişinde rol oynadığını göstermiştir. Ancak hipokampüsün moleküler ve nörokimyasal yapısını değiştirecek kadar yoğun yaşanan ve kronikleşen stres sonucunda erken yaşlarda unutkanlık başlar. Bu da stresini yönetemediği durumda çevirmenin zaman içinde sözlü çeviri mesleğini bırakması anlamına gelebilir.

Görüldüğü gibi, stresle baş etme noktasında bellek ve dikkat yönetiminde yetkinleşmemiş bir çevirmenin mesleki performansı tehdit altındadır. Sözlü çeviri yaparken verdiği tepkileri tanıyan ve kişilik özelliklerinin performansı üstündeki etkilerini anlayan bir çevirmen, bu zorlu süreci başarıyla yönetebilir. Stres tepkilerinin yoğunluğunu kişilik özelliklerinin belirlediğini gösteren çalışmalarda kişinin stres yaratan durumu değerlendirme biçiminin ve algısının; biyolojik, psikolojik ve davranışsal tepkilerini belirlediği görülmüştür. Bir başka deyişle, kişi stresle nasıl başa çıkabileceğini biliyorsa, kendine güveniyorsa, tutarlı ve yapıcı bir yaklaşıma sahipse, ayrıca duygudurumunu yönetebiliyorsa stresten olumsuz yönde etkilenmeyebilir. Olff ve araştırma grubu (1993), stresle başa çıma stratejilerinin stres algısını doğrudan etkilediğini bulgulamıştır. Bu noktada baskılama ya da gerçekçi olmayan bir biçimde durumdan uzaklaşma, kişinin kaçma davranışı geliştirmesine ve strese bağlı korkuların yerleşmesine neden olabilir. Çeviri sürecinde yoğun stres yaşayan ya da çeviri sırasında başarısız olma kaygısı taşıyan bir çevirmen; karşısına çıkan çeviri fırsatlarını duyduğu özgüven eksikliği nedeniyle tepmek yerine, stresinin ve kaygısının nedenini araştırıp zayıf olduğunu düşündüğü alanlarda 
kendini güçlendirerek, yeni beceriler ve stratejiler geliştirerek, artalan bilgisini derinleştirerek ve sık sık uygulamalar yapıp belleğini güçlendirerek stres tepkisini en aza indirebilir. Böylelikle giderek kendine daha çok güvenmeye başlayacağından strese dayanıklılık eşiği de yükselecektir. Güven duygusu, kişinin fiziksel ve ruhsal dengelerine yansır; bir yandan da bağışıklık sistemini güçlendirir (Reiche, Nunes ve Morimoto, 2004).

Yapılan bir araştırmada, sadece araştırmalarda kullanılmak üzere laboratuvar koşullarında yetiştirilen köpeklerin, dışarıdan getirilen köpeklere göre, öğrenilmiş çaresizlik belirtileri sergiledikleri gözlenmiştir (Seligman, 1992; Sapolsky, 2004). Seligman'a (1992) göre bunun nedeni, dış dünyada hayatta kalmaya çalışan köpeklerin, kontrol edemedikleri bir durumla karşılaştıklarında bu durumun dünyanın sonu olmadığını bilmeleri; böylece o an yaşadıkları deneyimi genelleyerek çaresizlik içine girmemeleridir. Bu araştırmadan yola çıkarak deneyimi sınırlı olan çevirmenlere, kendi kontrolleri altında yaratacakları deneysel ortamlarda, gerçek yaşamda karşılaşabilecekleri türden sorunları, zorlukları ve engelleri içeren deneyimler tasarlamalarını önerebiliriz. Dış dünyada karşılaşabilecekleri zorlukların içine kontrollü biçimde girdiklerinde doğal olarak verecekleri tepkileri, oluşturacakları dirençleri tanımaları durumunda ortaya çıkacak farkındalık ve kişilik özelliklerine yönelik daha derin bir kavrayış onları gerçek çeviri deneyimine hazırlayacaktır. Böylece kendi tasarladıkları güvenli uygulama ortamlarında yaşayacakları zorlayıcı deneyimler sırasında sorunlara özgü geliştirecekleri çeşitli stratejileri kullanmak, alacakları geribildirimleri değerlendirmek yoluyla zorluklardan ve başarısızlıklardan güçlenerek çıkmayı öğrenmiş olurlar.

Özetleyecek olursak, stres altında beyin bilişsel etkinlikler ve yüksek düzeyli yürütücü işlemler yerine fiziksel mücadeleyi öncelemektedir. Çevirmenin kontrol edemediği bir stres altında çalışması da duyusal belleğin sadece hayatta kalmaya yönelik uyaranları farkındalı̆̆a sunması anlamına gelir. Dinlenme durumu ağlarının yukarıdan-aşağıya dikkatini engellemesi sonucu ise çevirmen; dikkatini konuşmacıya değil, yalnızca kaygı yaratan içsel uyaranlara yöneltir. Böylece süzülen uyaranlar arasında konuşmacının aktarmakta olduğu ayrıntılar da yer alacağından çeviri kalitesinde ciddi kayıplar söz konusu olacaktır.

Bu nedenle sözlü çeviri yapacak çevirmenlerin eğitiminde dikkat türleriyle birlikte stresin tüm evrelerine ve dikkat-stres arasındaki ilişkiye yer verilmesi, ayrıca stresi yönetmeyi sağlayacak odaklanma ve nefes tekniklerinin öğretilmesi önem taşımaktadır (McCraty ve Childre, 2003; 2004); çünkü sözlü çeviri sürecinde stresin kontrol altında tutulabilmesi ve yönetilebilmesi bir gerekliliktir. Böylelikle çevirmen, strese yönelik bilgi altyapısı oluşturur, strese karşı dayanıklılık geliştirebilir, stres karşısında esneklik kazanabilir ve stres yaratan koşullar karşısında yeni beceriler geliştirerek sorun çözümünde yetkinleşebilir. Stresini denetlediğinde dinlenme-durumu ağlarının yönetiminden çıkan çevirmen, yukarıdan-aşağıya dikkatini hızla akıp gitmekte olan konuşmaya kesintisiz olarak odaklayabilir; böylece kulağına gelmekte olan bilgi çalışma belleğine girer, orada işlenir ve çevirmen böylece konuşmaya ilişkin sağlıklı bir kavrayışa ulaşır.

\section{Kısa süreli bellek ve çalısma belleği}

Duyusal bellekte süzülmeyip akılda tutulan bilgi, üzerinde çalışılmakta olan işin tamamlanmasına yarayacak işlevsel bilgidir. Çalışma belleğine aktarılan bu bilgi, beynin ön loblarında, özellikle ön alt kortekste ve şakak loblarında işlenir. Çalışma belleğinden söz ettiğimizde deneyimlerimizin farkında olmamızı sağlayan bir sistemden söz etmiş oluruz. Yaptıklarımızın, duyduklarımızın, gördüklerimizin farkında olmamızı bu sistem sağlar. 


\section{Kisa süreli bellek.}

Çalışma belleği bilişsel donanımımızın yetkin çalışmasını sağlamak ve bilişsel sorun çözümünü gerçekleştirebilmek için kısa süreli bellek yapılarından yararlanır. Kısa süreli bellek dendiğinde hemen akla gelen bir örnek telefon numaralarının geçici olarak ezberlenmesidir. Önemli sınırlılıkları olan bu bellek türü yoğun dikkat ve odaklanma ister; bu da çevirmenin yukarıdan-aşağıya dikkat sistemini başarıyla yönetmesi anlamına gelir.

Kısa süreli belleğe kodlanan bilgi yinelenmediğinde zaman içinde hızla unutulur. Ardıl çeviri sürecinde not tutmakta olan çevirmenin ise hızla akmakta olan bilgiyi yineleyerek akılda tutmaya çalışması olanaksızdır. Bunun yerine bu sınırlılığı bilerek konuşma süresince dikkatini konuşmanın üstünde tutmasını sağlayacak şekilde dikkat odaklama becerisi ile not tutma becerilerini uygulama yaparak geliştirmesi gerekmektedir. Bağlam dışında kendi başına bir anlam taşımayan ve daha çok ad, kurum ve kuruluş adları, rakam, sayı, listelerde yer alan ögeler gibi ilk kez duyulduğunda akılda kalması zor olan noktaları hızla not edebilmelidir (Roche, 1999). Ancak konuşmayı ana noktaları ve önemli ayrıntılarıyla aklında tutmak zorundadir.

Yeni gelen bilgi kısa süreli bellekte sadece kısa bir zaman boyunca, yaklaşık 15-30 saniye süreyle kalabilir (Terry, 2006). Bu kısa süre içinde sadece belli miktarda bilgi bellekte tutulur. Anlam oluşturma sırasında bellekte tutulan bilginin 5-9 birim arasında değiştiği düşünülmektedir (Terry, 2006). Bir başka deyişle, kısa süreli bellek birim zamanda birbiriyle ilişkili olmayan en fazla dokuz rakamı, harfi ya da sözcüğü saklama kapasitesine sahiptir. Eğer bilgi, kümeleme stratejisi kullanılarak daha geniş ve anlamlı bir birime dönüştürülürse daha fazla bilgi akılda tutulabilir. Kümeleme stratejisine bir örnek verecek olursak, “e, i, v, t, ü, s, n, r, i, e" harflerini birbirinden ayrı harfler ya da sesler olarak akılda tutmaya çalışmak yerine bu harfleri anlamlı bir sözcüğe, "üniversite” sözcüğüne dönüştürdüğümüzde sözcük rahatça anımsanabilir. Bu stratejiye bir de çeviri bağlamında örnek verelim. Konuşmacının birbiriyle anlam bağı olmayan bir dizi sözcük sıraladığını düşünelim. Ülkemizi ziyaret etmekte olan heyetin önce Ankara'da ağırlanacağı, daha sonra ise sırasıyla Rize, Manisa, Urfa ve Trabzon'a götürüleceği belirtilmiş olsun. Adı geçen kentler baş harflerinden yola çıkarak kümelendiğinde anlamlı bir sözcük olan ARMUT akronimine dönüştürülebilir; böylece çevirmen hem kent adlarını not alma yükünden kurtulmuş olur hem de akronim kolayca aklında kalır. Bu anlamda çok sayıda uygulama yapıldığında beyin, örnekte verilen kümelemeyi ya da akronim oluşturmayı kendiliğinden yapar. Ayrıca ARMUT'ta yer alan harflerin temsil ettiği kentler, A (Ankara) merkez alınarak dizildiğinde, Ankara'ya göre bulundukları konumla uyumlu oklarla gösterildiğinde, yani yönlerini gösteren semboller kullanıldığında, aynı harfle başlayan başka kentlerle karıştırımayacak, anımsanmaları daha kolay olacaktır. Söz gelimi, Manisa ile Malatya, Urfa ile Uşak çevirmenin belleğinde birbirinin yerine geçmeyecektir. Ancak eğer çevirmen eğitimi boyunca dersler ve ödevler dışında kümeleme ve sembol kullanımı stratejilerini çeviri sırasında rahatça kullanmasını sağlayacak pek çok uygulama yapmamışsa ardıl çeviri sırasında bu teknikleri kullanması kolay olmayacaktır.

Sözlü çeviri sürecinde, kısa süreli bellek kapsamında ele aldığımız çalışma belleğini destekleyici stratejilerin kullanılması, çalışma belleğinin sınırılıklarını aşma noktasında çevirmene yardımcı olur. Yapılan bir araştırmada, Hacettepe, Mütercim-Tercümanlık Bölümü öğrencileri ile Hacettepe Tıp Fakültesi öğrencilerinin belleklerine binen yükün benzerlik göstermesinden dolayı her iki grubun da kısa süreli bellek puanlarının birbirine yakın olduğu saptanmıştır (Doğan \& Kafadar, 1998). Bir başka deyişle, sözlü çeviri yapan bir çevirmen tıp öğrencileri kadar bilgiden yana yoğun bir yük altındadır ve tıp öğrencilerinin sahip olduğu bellek yetkinliğine sahip olması gerekmektedir. Çevirmenlerin 
kullanabileceği çeşitli bellek stratejileri belleklerine binen yükü hafifletebilir. Kısa süreli belleğin yükünü hafifletebilecek önemli bir strateji, çevirmenin duyduğu sözcükleri ve tümceleri tek tek akılda tutmak ya da nota çevirmek yerine kavramlara dönüştürmesi; konuşmada ifade edilen fikirlere ve fikirler arasındaki bağlantılara, ayrıca konuşmanın bütününde ortaya çıkmakta olan anlama odaklanmasıdır. $\mathrm{Bu}$ yolla çevirmen, "derin işlemleme" stratejisinden yararlanmış ve yukarıdan-aşağıya dikkatini odaklayarak uzun süreli belleğin kapısını aralamış olur (Madigan, 2015, s. 56).

Craik ve Tulving (1975, Madigan, 2015 içinde) bu çerçevede yapmış oldukları bir araştırmada öğrencilere, seçtikleri sözcüklere ilişkin çeşitli sorular sorarak soruların, sözcüklerin öğrencilerin belleğine yerleşimini nasıl etkilediğini görmek istemişlerdir. Araştırmada, farklı tür soruların öğrencilerin sözcükleri anımsama düzeyini belirgin ölçüde etkilediği görülmüştür. Soru, büyük ya da küçük harfle yazılması gibi sözcüğün görünüşüyle ilgili olduğunda öğrenciler sözcükleri daha az anımsayabilmişlerdir. Soru, sözcüğün uyaklı olup olmaması gibi sesli ifadesi ile ilgili olduğunda ise anımsama oranı daha yüksek olmuştur. Ancak sözcüklerin anlamına ilişkin sorular sözcüklerin anımsanmasına belirgin ölçüde katkı sağlamıştır. Öğrenciler sözcüğün anlamını kavradıklarında ve sözcüğü kullanmaya çalıştıklarında akılda tutma oranı en yüksek düzeye ulaşmaktadır. Araştırmacılar, sözcüğün anlamına ilişkin soruların daha derin bir zihinsel işlemleme gerektirdiğini ve bu derinliğin daha güçlü bir anı oluşumuna yol açtığını ifade etmektedirler (Madigan, 2015). "Sözcüklerin görünüş ya da duyuluş gibi yüzeysel özellikleriyle ilgili olan sorular, sözcüğün temsil ettiği anlama değinmeyi gerektirmeyen sığ işlemlemeye yol açmıştır" (Madigan, 2015, s. 56). Sığ işlemleme sonucunda belleğin sözcüklere ilişkin aldığı kayıt son derece zayıftır. Madigan bu durumu şöyle ifade etmektedir:

Belleğe girecek herhangi bir bilgiyle bu düzlemde temas ettiğimizde çabalarımız sonucu daha zengin, yerleşik ve korunması daha olanaklı olan anılar ortaya çıkar. Derin işlemleme, beyin taramalarında da beynin bellekle ilişkili önemli bölgelerinde artan etkinlik olarak kendini gösterir. Beyinde artan bu etkinlik sonucunda derin işlemleme belleğin güçlenmesini sağlıyor gibi görünmektedir. (Madigan, 2015, s. 56)

Derin işlemleme stratejisini kullanmayı destekleyecek bir etkinlik, yazılı bir metinde ya da konuşmanın akışı içinde fikirlerin birbirleriyle olan ilişkisine, fikirler arası geçişlere, ana fikirler ile yan fikirleri birbirinden ayıran ifadelere ve ana fikirler ile ayrıntılar arasındaki ilişkilere odaklanmak ve bu yapısal örüntüyü görsel olarak bir zihin haritasına dönüştürmektir. Bu uygulama derin işlemlemeye yol açacağı için, Craik ve Tulving'in (1975) yapmış olduğu araştırmada da gösterildiği gibi, fikir örüntülerinin ve onları ifade eden kavramsal yapıların akılda kahıcılı̆̆ını artıracaktır. Bu uygulama derin işlemleme, yani derin çözümleme gerektirdiğinden ve ardıl çeviri sürecinde çözümleme aşaması not tutma aşamasına denk geldiğinden, not alırken zihin haritası oluşturmak, konuşmaya ilişkin geniş tabloyu görmek, anlamak ve sonrasında bu tabloyu okumak şeklinde olacaktır.

Çevirmenin eğitimi boyunca ders dışındaki zamanını değerlendirerek strateji uygulamaları yapması sonucu çalışma belleğinin bilgi tutma kapasitesi gelişecektir (Doğan ve Kafadar, 1998). Buna ek olarak, çeviri yapılacak alana ve konuşması çevrilecek kişilerin daha önce yapmış oldukları konuşmalara ilişkin artalan bilgisi oluşturmak ve hızlı not tutmayı sağlayacak şekilde zengin sembol ve kısaltma dağarcığına sahip olmak kısa süreli belleğin kapasitesinin sınırlı oluşuyla gelen engellerin aşılmasını sağlayabilir. Çalışma belleği ve kısa süreli bellek kapsamında önemli olan imgeleme ya da zihinsel resim oluşturma burada önem kazanmaktadır, çünkü çevirmen eğer not tutarken konuşmanın yapısından yola çıkarak aklında ya da sayfasında bir zihin haritası oluşturabilirse bilginin akılda kalıcılığını artırabilir ve kısa süreli belleğini desteklemiş olur. Konuşmanın yapısının çözümlenmesi ve sözün imgeye dönüştürülmesi sırasında beynin yaratıcllıtan ve imgelemeden sorumlu sağ lobu etkinleşecektir. Beynin sağ lobu, 
konuşmanın vurgusunun, ritminin algılanmasını ve geniş resmin görülmesini destekler (Wolfe, 2001). Böylece bilginin kalıcılığı artacaktır, çünkü kavramların sembollerle, fikirlerin de görsel imgelerle ifade edildiği şekiller anımsamayı kolaylaştırır (Madigan, 2015, s. 36).

Konuşma sırasında alınan notlar, konuşmacı çevirinin yapılması için konuşmasına ara verdiğinde anlamlı ve tutarlı bir çevirinin yapılmasını sağlayacak şekilde hem artalan bilgisini hem de konuşmacının dile getirdiği fikirleri ana ve alt başlıklarıyla akla getirecek şekilde tetikleyici olmalıdır. Konuşmada ele alınan ana fikirlerle yan fikirler birbiriyle ilişkilendirildiğinde açıklamalar, örnekler ve ayrıntılar belirli bir düzen içinde uzun süreli bellek yapılarına kodlanır ve bunun için büyük bir çaba gerekmez. Ardıl çeviride konuşma 3-5 dakikalık uzun bölümler halinde çevrildiğinden uzun süreli bellek yapıları da devreye girmektedir. Kısa süreli bellekte tutulan bilginin uzun süreli belleğe aktarımını sağlayan bazı koşullar vardır.

Heyecan uyandıran, çarpıcı olan, duygusal olarak bağ kurduğumuz, artalan bilgisine sahip olduğumuz için bize anlamlı gelen ya da günlük yaşamda gerekli olan bilgi çabasızca uzun süreli belleğe aktarılır. Çevirmen bir konu hakkında kapsamlı ve derin artalan bilgisi oluşturduysa ve bu bilgiden günlük yaşamında da yararlanıyorsa bu bilgi, kolayca ulaşabileceği şekilde uzun süreli bellekte yerini alır. Ancak birbiriyle bağlantısı ve anlam bütünlüğü olmayan, tek başına bir anlam ifade etmeyen rakam, sayı, ad, harf, kısaltma, kurum ve kuruluş adları, liste maddeleri ya da formüllerle ifade edilen bilgi birimciklerinin uzun süreli belleğe kodlanması için yineleme ve ezber gerekir. Ancak ardıl çeviri sırasında yineleme ve ezber için zaman olmadığını yukarıda belirtmiştik. Çevirmen bu tür bilgiyi ya sembol ve kısaltmalar kullanarak hızlıca not etmeli ya da ögeler arasında anlamlı bağlar kurarak, ögeleri kümeleyerek ya da öyküleme yoluyla bilgi birimciklerini akılda tutmaya çalışmalıdır. Ancak konuşmanın hızlı akışı sırasında tek başına anlam ifade etmeyen ögeleri akılda tutmak için bu yöntem yetersiz kalabilir. Bunun yerine hızlı not alma becerisinin gelişmesi için yoğun uygulamalar yapmak gerekmektedir. Ayrıca çevirmen çeviriye başlamadan önce karşllaşabileceği kurum ve kuruluş adlarını, konferansı düzenleyen kişi ve kuruluş adlarını küçük kağıtlara not ederek yanında bulundurma yoluna da gidebilir. Bu tür bir önlem yine kısa süreli belleğin ve çalışma belleğinin yükünü hafifletecektir.

Çevirmen, konuşmanın konusunu oluşturan ana fikirler ve alt başlıklar arasında konuşmacının izlemekte olduğu mantıksal yapıdan özgürleşerek kendisi için anlamlı olan çağrışımsal bağlar kurabilir, kavramları sınıflandırma yoluna gidebilir ve böylece bilginin akılda kalıcılığını artırabilir. Dinleme ve not tutma eylemi sırasında dile getirilen ana fikirlerin ve yardımcı fikirlerin kavramsal olarak ilişkilendirilerek anlamlı bir bağlam ve yapısal bir bütünlük içine yerleştirilmesi sürecinde yukarıdanaşağıya dikkatinin yardımıyla odağını yöneten çevirmen, bilginin güçlü ve sistemli olarak kodlanmasını sağlar. Bu da çeviri sırasında anımsamaya doğrudan etki eder. Not tutarken ana fikirleri doğrudan akla getirecek şekilde tetikleyici sözcük, kısaltma ya da sembollerin kullanılması, ana fikirlerle bağlantılı olan yan fikirleri ve ayrıntıları kolayca anımsamayı sağlayacaktır. Tetikleyici sözcük, ifade ya da sembollerin kullanımı oldukça önemlidir, çünkü tetik olmadığında uyuyan bilgi tetikle birlikte uyanır ve ilişkili olduğu diğer bilgi birimciklerini çağrışım yoluyla akla getirir (Madigan, 2015).

Siegfried Woldhek'in "How to Find the True Face of Leonardo" (Leonardo'nun Gerçek Yüzünü Nasıl Bulabiliriz) başlıklı konuşmasını bu stratejiye yönelik olarak inceleyelim. Konuşmacı konuşmasının başında sanatçının olağanüstü eserlerini çizimleri, icatları, resimleri ve yazıları olarak ele almakta, karşılaştığı her şeyi, özellikle insanları, anatomik yapıyı, bitkileri, binaları, suları, hayvanları ve manzaraları çizdiğini belirtmekte, ancak kendi yüzünü çizmemiş olmasının inandırıcı olmadığını vurgulamaktadır. Bir dakikalık süre içinde konuşmacı iki sözcük listesi yapmaktadır. Listelerin akılda 
kalması için kümeleme, sınıflandırma ve zihin haritası stratejileri birlikte kullanılarak zihinde iki tane yapısal döküm oluşturulabilir. Bunlardan ilki tetikleyici sözcük öbeği olarak "olağanüstü eserler" ifadesini içerdiğinde ve aşağıdaki şekilde görüldüğü gibi kodlandığında dört eser türü akla gelecektir.

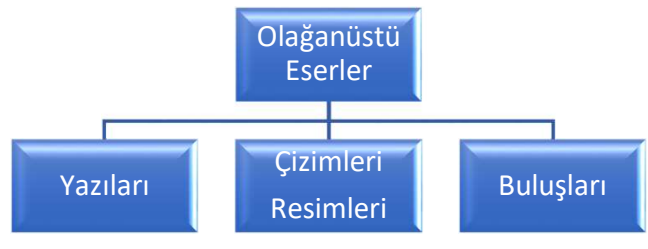

Diğerinde ise "Çevresindeki her şey" tetikleyici olduğunda ve bilgi aşağıda görüldüğü gibi üç başlık altında kodlandığında yedi öge akla gelecektir:

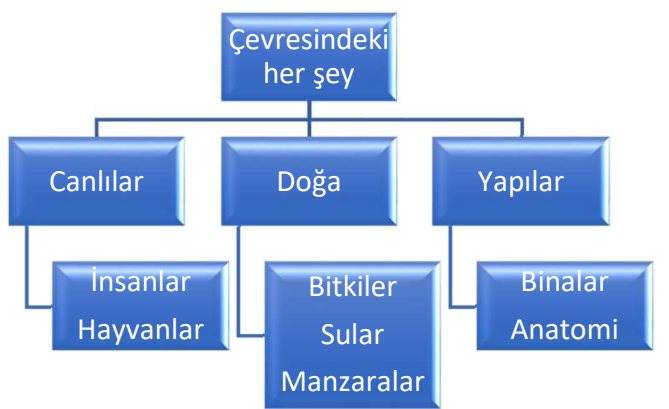

Konuşmanın yapısının zihin haritasına dönüştürülerek çözümlenmesine ilişkin yapılacak uygulamalar sonucunda beyin bir süre sonra benzer çözümlemeleri doğal olarak yapmaya başlar. Böylece zihinde görsel haritalar çözümleme aşamasında kendiliğinden ortaya çıkar.

Bilgiyi kodlarken farklı bir odağa yönelmek, gelmekte olan bilgiyi kaçırma korkusuna kapılmak ya da gürültü veya hareket nedeniyle dikkatin dağılması, yani dinlenme durumu ağlarının ve aşağıdanyukarıya dikkatinin devreye girmesi, kodlamayı olumsuz yönde etkiler. Bu sırada gelmekte olan yeni bilginin, kısa süreli olarak bellekte tutulmaya çalışılan yeni bilgi kümesi üstünde bozucu bir etki yaratarak unutmayı hızlandırdığını vurgulayalım. Benzer şekilde, var olan bilginin de yeni edinilmekte olan bilgi üstünde bozucu bir etkisi olabilir (Morgan, 2004). Bozucu etkiyi güçlendiren en önemli öge, iki konu arasındaki benzerliktir (Morgan, 2004).

Çevirmen bilgi birimcikleri arasında anlamlı bağlar kuramazsa, bilgiyi artalan bilgisinin yardımıyla anlamlı bir bağlam içine yerleştiremezse ve artalan bilgisinin yeni gelmekte olan bilgi üzerinde bozucu etki yaratıp yaratmadığını yürütücü biliş ile denetleyemezse bilginin uzun süreli belleğe kodlanması sürecinde iki temel sorun ortaya çıabilir:

1. Bilgi kaybolup gidebilir;

2. Yeni gelmekte olan ve var olan bilgi birbirine karışabilir. 
Bu noktada çevirmen, benzerliklerden kaynaklanan bozucu etkinin bilincinde olmalı ve kurgulayacağı bağlam örüntüleri yoluyla bilgiyi ait olduğu bağlamla birleştirerek bozucu etkiyi en aza indirgeyebilmelidir. Yukarıdaki örnekte, eğer sınıflandırma yoluna gidilmezse, ardıl çevirinin doğası gereği araya giren zamana bağlı olarak, peş peşe sıralanmakta olan sözcükler birbirine karışabilir, unutma ortaya çıkabilir ve böylece anlam karmaşası oluşabilir.

\section{Çalışma belleği.}

"Çalışma belleği yürütücü işlemlerden sorumludur; plan yapmamızı, dikkatimizi yönlendirebilmemizi, stratejiler kullanmamızı ve işleri başından sonuna kadar yürütebilmemizi sağlar. Aynı zamanda da geçici bir bellek ağı olarak gelip geçen bilgileri sisteminde tutar" (Madigan, 2015, ss. 26-27). Kısa süre akılda kalacak bir bilginin imge olarak ya da iç ses yardımıyla yinelenerek akılda kalmasını (Madigan, 2015, s. 27), görsel-işitsel uyaranlara odaklanmayı ve dikkatin değişik uyaranlara yöneltilebilmesini, anlamlı çıkarımlar yapabilmeyi sağlar. Çalışma belleği "planlama, yöntem geliştirme ve bir işi baştan sona götürebilme becerilerini" kapsadığından "yürütücü işlevler" adı verilen üst düzey bilişsel işlemlerden sorumludur " (Madigan, 2015, s. 26). Tüm bunlara ek olarak gelmekte olan bilgiyle var olan artalan bilgisinin bütünleştirilmesini de yönetir.

Çalışma belleği, dinleme yoluyla elde edilen dilsel bilginin kullanılması gereken kısa süre boyunca akılda kalmasını sağlar. Görsel ya da işitsel kanallarla gelen bilgi zihinsel resimlere dönüştürülür ve kısa bir süre boyunca saklanır. Beş duyudan gelen bilgiyi akılda tutabilmek için tıpkı bir orkestra şefi titizliğinde dikkati ve odağı yönetir. Çalışma belleği orkestrasını hatasız yönetebilmek için yukarıdan-aşağıya dikkatinden yararlanır. Herhangi bir bilginin çalışma belleğine ulaşabilmesi için bu dikkat türüne gereksinim vardır (Madigan, 2015). Bir başka deyişle, kişi bir olaya, duruma ya da işe tam odaklandığında yukarıdan-aşağıya dikkati nedeniyle bilgi çalışma belleğine erişebilir. Yoksa çalışma belleği hiçbir kayıt almaz ve kişi söz konusu bilgiyi belleğinde tutamadığını ya da unuttuğunu düşünür. Aslında odağını bilinçli olarak yönetemediği için bilgi belleğe girememiştir bile.

Ardıl çeviri sırasında yukarıdan-aşağıya dikkati, çevirmenin duymakta olduğu konuşmaya odaklanmasını ve duyulan konuşmaya ilişkin ayrıntıların çalışma belleğine girmesini sağlar. Böylece duyduğu sözcükler anlam ortaya çıkana kadar çalışma belleğinde tutulur ve işlenir. Konuşmacı sustuğunda ve çevirmen çevirisine başladığında çalışma belleği yoluyla düşüncelerini düzenler, söyleyeceklerini planlar, konuşmacının yaratmak istediği izlenimi yaratmasını sağlayacak sözcükleri seçip kullanır. Çalışma belleği fikir yürütmek, dilsel dinamiklerden yararlanarak konuşmacının düşünce akışını izlemek, konuşmacının vermek istediği iletiyi etkili biçimde aktarmak ve bu süreçte yaşanabilecek sorunları çözmeye çalışmak gibi çeşitli bilişsel süreçleri yönetir. Çevirmen bir kez konuşmacının ulaşmak istediği hedefi çözümlediğinde çalışma belleği yardımıyla hedefinden şaşmadan çevirisini yapar. Çevirmenin dinlediği konuşmayı harfi harfine anımsaması gerekmez. Söylenenlerin bütünsellik içinde kavranmasıyla ortaya çıkan anlamı destekleyecek ayrıntılar uzun süreli kodlama için beynin ilgili bölgelerine gönderilirken gereksiz ayrıntılar farkındalıktan uzaklaştırılır.

Üniversite öğrencileri üzerinde yapılan araştırmalar; okuduğunu anlama, metinlerden ayrıntı anımsama, bilinmeyen sözcüklerin anlamını bağlamdan çıkarabilme ve akıl yürütme becerilerini yetkin biçimde kullanan öğrencilerin çalışma belleği kapasitesini iyi kullanabilen öğrenciler olduğunu göstermiştir (Madigan, 2015). Bir başka deyişle, çalışma belleği güçlü olan ve bu bellek kapasitesini yukarıdan-aşağıya dikkatini yöneterek etkin kullanabilen çevirmenler, ardıl çeviri sırasında duyduğunu 
anlayıp anlamlandırma, ayrıntıları akılda tutma, bilmediği sözcüklerin anlamını kestirebilme ve konuşmanın gidiş yönüne ilişkin fikir yürüterek geniş resmi görme konusunda zorluk çekmeyeceklerdir.

Yukarıdan-aşağıya dikkati uzun süreli bellek oluşumunda da önemli rol oynar. Çalışma belleği, çevirmenin dinlemekte olduğu konuşmada irdelenen konuyu çözümleyebilmesi için uzun süreli bellekte tutulan bilgiden yararlanmasını sağlar. Ayrıca uzun süreli bellekte depolanmış bilgiyle yeni gelmekte olan bilgiyi bütünleştirme görevini de yürüttüğü için gelmekte olan uyaranlar uzun süreli bellekte bulunan bilgiler çerçevesinde ele alınır ve anda durumun kendine özgü zengin yorumu olarak, yani çevirmenin kendi yaratıcı sentezi olarak sunulur. Böylece hem yeni bilgiyi artalan bilgisiyle birleştirip anlam örüntülerinin genişletilmesi sağlanmış olur hem de konuya ilişkin gerekli bilgiye, yani uzun süreli bellekte depolanmış bilgiye erişim sağlanmış olur. Ancak burada yürütücü bilişe önemli bir rol düşmektedir. Çevirmen kendi yaratıcı sentezini dile getirirken konuşmacının söylemediği hiçbir şeyi dile getirmemelidir. Bunun kontrolü yürütücü biliştedir. Çünkü yürütücü biliş yardımıyla çevirmen, yapmakta olduğu çeviriyi izleyerek konuşmacının söyledikleriyle kendi artalan bilgisinden çağırıp kullandığı ve söylenenlerden farklı olan bilgileri ayırt edebilir. Bu çerçevede yürütücü bilişi geri bildirim verirken çevirmen, öyküleme yapıp yapmadığını, yani güvenilir bir çeviri yapıp yapmadığını denetlemiş olur.

\section{Yürütücü biliş}

Yürütücü biliş, Veenman, Van Hout-Wolters ve Afflerbach'ın (2006) tanımıyla, bilişsel süreçlerin işleyişini izlemek olarak tanımlanmaktadır. Bir benzetme yapacak olursak, yürütücü biliş, bahçede yapılan ekim-dikim çalışmalarına bir kat yukarıdan, balkondan bakmak, yapılan işi bir yandan izleyip denetlemek bir yandan da yapılanlara yönelik geri-bildirim sağlamaktır. Bu örnekten de anlaşlacağı gibi, bilişsel etkinliklerle yürütücü biliş arasında bir yandan önemli bir ilişki ve etkileşim varken bir yandan da doğaları açısından belirgin bir farklılık bulunmaktadır. Veenman, Van Hout-Wolters ve Afflerbach'a (2006) göre, bilişsel işleyişin olmadığı yerde yürütücü bilişten söz edilemez.

Yürütücü bilişin dinlediğini anlama sürecine katkısını araştıran bir çalışmada, yürütücü biliş stratejilerinin öğretiminin, öyküleyici ve bilgilendirici metin türlerine yönelik dinlediğini anlama becerilerinin gelişimine olumlu yönde katkı sağladığı görülmüştür (Katrancı ve Yangın, 2013). Bir başka deyişle, ardıl çeviriyi oluşturan dinleme, anlama, not tutma ve çeviri evrelerinin her biri yürütücü biliş stratejilerinin kullanımı sonucunda güçlenir. Çevirmenin duyduklarını anlamlandırma çabası ve ifade etme çabası bilişsel etkinliğe bir örnek oluştururken bu bilişsel etkinlik sırasında konunun tam olarak kavranıp kavranmadığının farkındalığı ile akıcı, doğru ve etkileyici biçimde dilsel bir aktarımın sağlanıp sağlanmadığının izlenmesi ve denetlenmesi yürütücü biliş becerisine örnek oluşturur. Bu süreçte ortaya konan çeviri performansı yürütücü biliş tarafından düzenlenir, değerlendirilir ve bu değerlendirmeye bağlı olarak sonraki adımlar planlanır. Bir yandan da bu sırada ortaya çıkan duygular izlenir ve denetlenir (Brown, 1994). Sürecin tümünün izlenip değerlendirilmesi devamlllık gösterir (Veenman, Van Hout-Wolters ve Afflerbach, 2006).

Ardıl çeviri sırasında yürütücü biliş stratejileri kullandığında çevirmen:

a. Fikirler arasında anlamlı bağlantılar kurup kurmadığını denetleyebilir,

b. Gerçekçi çıkarımlar yapıp yapmadığını saptar,

c. Anlamı destekleyecek bağlamsal ipuçlarını bağlama uygun biçimde değerlendirip değerlendirmediğini fark eder, 
d. Dikkatini denetleyip yönetebilir,

e. İlerleyen konuşmanın öncesinde verilen bilgilerin aklında kalıp kalmadığını saptar,

f. Yaptığı çevirinin anlamsal ve mantıksal bütünlüğünün olup olmadığının ayrımına varır,

g. Hatasız, akıcı ve olabildiğince eksiksiz bir çeviri yapıp yapmadığının bilincine varır,

h. Çeviri sırasında eksik bilgiye bağlı olarak ciddi atlamalar yapıp yapmadığını ve atladığı ögeler varsa bunların konuşmanın bütünlüğü üstünde olumsuz bir etki yaratıp yaratmadığını bilir.

Ardıl çeviri sırasında yürütücü bilişin en önemli katkısı, çevirmenin öyküleme yapıp yapmadığı doğrultusunda geribildirim sağlamasıdır. Bu doğrultuda yürütücü biliş yetkinliğini geliştirecek uygulamalar içinde konuşmanın ayrıntılı biçimde kavranmasının sağlanması önemli bir yer tutar. Öncelikle konuşmacının seçmiş olduğu sözcükler, fikir düzeni, fikirler arası bağlantılar ve ele alınan ayrıntı ve örnekler çerçevesinde oluşan genel tabloyu öğrencinin görmesi gerekir. Ardından seçilmiş sözcüklerle ve ses tonuyla yaratılan vurgu, kullanılan kesitdil ve buna bağlı olarak ortaya çıan iletinin tam olarak kavranması gerekir. Bu yürütücü bilişin sağlayacağı denetim açısından gereken alt yapıyı sağlar. Kavrayış ortaya çıktıktan sonra aynı içeriği öğrencinin kendi ifadeleriyle, anlamda, vurguda ve ileti bütünlüğünde eksik olmayacak şekilde ifade etmesi istenmelidir. Bu sırada öğrenci kavramış olduğu özgün konuşma ile kendi yorumu arasındaki benzerlikleri ve farklllıkları izlemeye ve gereken düzeltmeleri yapmaya yüreklendirilir. Öz değerlendirmenin ardından sınıf arkadaşlarından bir değerlendirme istenir. Öz değerlendirme kapsamında konuşmanın anlamı, vurgusu, içerdiği ileti yanında çevirinin yapıldığı dilin akıcı olup olmadı̆̆ı, doğruluk değerinin yüksek olup olmadığ ve dile özgü kültürel ögelerin yabancılaştırılmadan aktarılıp aktarılmadığı önem kazanmaktadır. Üçüncü adım ise bir hatanın ya da eksiğin görüldüğü noktada öğrencinin kendini düzeltebilmesine olanak tanımaktır. Öğrenci hem kavrayışını, hem düşünce sistematiğini hem de dilsel performansını değerlendirip kendini düzeltebilmeli, özgün konuşmaya karşllı gelecek yetkin bir çeviri yapıp yapamadığının ayrımına varabilmelidir.

Çevirmenin hem eğitimi sırasında hem de profesyonel deneyimi boyunca yürütücü biliş stratejilerini kullanarak uygulamalar yapması sonucunda stres ve zaman yönetimi, öz değerlendirme, performansını izleme ve kendini düzeltme becerileri gelişecektir (Doğan, Arumi Ribas ve Mora-Rubio, 2009). Bu becerilerin her biri yapılan çevirinin kalitesini belirleyen temel unsurlar olduğundan çevirmenin farkındalıkla çok aşamalı bu çeviri sürecini yönetebilmesi, yürütücü biliş stratejilerinin kullanımında ne denli yetkinleştiğine bağlıdır.

\section{Sonuç}

Ardıl çeviri, çevirmenin önce tüm dikkatini odaklayarak konuşmacıyı dinlediği, dinlerken söylenenleri çözümlediği ve anlamlandırdı $\breve{g}$, bu sırada gerekli bilgileri daha sonra kolayca geri çağırabileceği şekilde belleğine kodladığı bir sözlü çeviri türüdür. Bu sırada çevirmen, konuşmaya ilişkin temel unsurları not defterine aktarmalıdır. Ancak bu sırada dikkatini konuşmacıdan not tutma sürecine kaydıracak olursa dinlemekte olduğu konuşmada geçen önemli noktaları kaçırabilir. Çevirmen ayrıca ana fikirleri, ana fikirler arasındaki bağlantıyı gösteren bağlaçları ve fikirler arasındaki bağlantıları not alırken (Roche 1999, Doğan, 1999) yan fikirleri ve ayrıntıları akla getirecek şekilde görsel bir zihin haritası oluşturacak ve depoladığı bilgiyi tetikleyip geri çağırabilmesini sağlayacak sözcükler ve ifadeler kullanacak olursa çalışma belleğinin sınırlılığından özgürleşmiş olur. Sıra çeviriye geldiği zaman ise konuşmacının anlatı şablonu çevirmeni sınırlamaz; tersine çevirmen not aldığı konuşmayı istediği çerçevede, istediği yerden başlayarak, istediği cümle yapılarını kullanarak kendi özgün ifadesiyle, ancak özgün konuşmanın mantığına, anlamına, vurgusuna ve fikirler arasında kurulmuş olan ilişkilere sadık kalarak çevirebilir. 
Burada en önemli unsur çevirmenin, konuşmacının aktarmak istediği fikirleri, düşünceleri, duyguları, yaratmak istediği izlenimi ve vurgusunu tam olarak aktarması gereğidir (Roche 1999, Doğan, 1999). Bunun sonucunda belleğindeki bilgiyi geri çağırarak akıı bir biçimde kaynak dilden erek dile doğruluk değeri yüksek bir çeviri yapar.

Ardıl çeviri, çevirmenin belleğine büyük bir yük getirmektedir. Bu yük nedeniyle performans kaybı yaşanmaması için çevirmenin bellek türlerini ve belleğin işleyişini, dikkat türlerini ve dikkatin işleyişini iyi bilmesi, yürütücü bilişini geliştirerek performansını denetleyebilmesi ve süreç boyunca bellek ve dikkat sistemlerini yönetebilmesi gerekmektedir. Hızlı tempoda akan bir konuşmayı dikkati tam olarak odaklayarak dinlemek, bu sırada not almak, not alırken dikkati konuşmacının üstünde tutmaya devam etmek ve dikkat kayarsa yeniden odaklama çabası içine girmek, akıcı, doğru ve eksiksiz bir biçimde konuşmayı çevirmek için yürütücü bilişten yararlanmak; birçok bellek stratejisini kullanmayı ve dikkati farkındalıkla odaklamayı gerektirmektedir.

Çevirmeni son derecede zorlayan bu zihinsel sürecin üstesinden gelebilmenin temel koşulu, birbiriyle etkileşim içinde bulunan dikkat ve bellek sistemlerini tanımak ve birbirlerinin işleyişini nasıl desteklediklerini ve nasıl kösteklediklerini bilmektir. Yukarıdan-aşağıya dikkati, çevirmenin konuşmayı dinlerken bilgi kaçırmayacak şekilde tam odaklanmasını gerektirir. Bu sırada aşağıdan-yukarıya dikkatini tetikleyecek bir hareket ya da gürültü, dinlenme durumu ağlarını tetikleyecek bir duygu ya da düşünce ortaya çıkacak olursa bu iki sistem yukarıdan-aşağıya dikkatini dağıtacaktır. Bu dikkat türlerinin devreye girmesi ve yukarıdan-aşağıya dikkatini bozması çalışma belleğinin kısa süreli olarak bilgi tutma kapasitesini olumsuz yönde etkiler. Çevirmen duyusal belleğin gelmekte olan bilginin hangi noktalarda süzülmesi gerektiğine ilişkin vereceği kararların farkında olmazsa ciddi biçimde bilgi kaybıyla karşı karşıya kaldığını asla bilmeyecektir. Ancak çevirmen, kısa süreli bellek kapsamında yer alan çalışma belleğinin sınırlılıklarını bildiğinde ve çeşitli stratejileri yetkin biçimde kullandı̆̆ında bu sinırlılıkların üstesinden gelebilir. Dikkat sistemlerini yönettiğinde ve odağını konuşma üstünde kesintisiz biçimde tutarak konuşmanın anlamını çözümlediğinde ise çalışma belleğinin en önemli yardımcısı olan ve otomatik hale gelmesi gereken not tutma becerisinden tam olarak yararlanabilir. Tüm bu dengeleri kurabildiğinde çevirmen, ardıl çeviri sürecini yönetebilir; konuşmacının mantık çizgisini izleyip konuşmanın gidişini büyük ölçüde ve doğru olarak kestirebilir, verilen bilginin ana hatlarını ve gerekli ayrıntıları doğru, neredeyse eksiksiz olacak şekilde aktarabilir. Bunun sonucunda ortaya akıcı, güvenilir, konuşmanın özüne sadık ve kaliteli bir çeviri çıkmış olur.

\section{Kaynakça}

Bremner, J. D. (2005). Does stress damage the brain? Understanding trauma-related disorders from a mind-body perspective. New York: W. W. Norton \& Company.

Broadbent, D. E. (1958). Perception and communication. New York: Pergamon.

Brown, H. D. (1994). Teaching by principles: An interactive approach to language pedagogy. NY: Longman.

Doğan, A. (1999). Ardıl çeviri eğitiminde not almanın önemi ve not alma duyarlılı̆̆ının pekiştirilmesi. Hacettepe Üniversitesi Çeviribilim ve Uygulamaları, 55-63.

Doğan, A. ve Kafadar, H. (1998). Mütercim-Tercümanlık bölümü öğrencilerinin kısa süreli bellek düzeyleri. Hacettepe Üniversitesi Çeviribilim ve Uygulamaları, 197-205.

Doğan, A. (2011). Sözlü çeviri çalışmaları ve uygulamaları. Ankara: Siyasal Kitabevi.

Doğan, A., Arumi Ribas, M. ve Mora-Rubio, B. (2009). Metacognitive tools in interpreting training: A pilot study. Edebiyat Fakültesi Dergisi, 26(1), 69-84. 
Drevets, W. C. ve Raichle, M. E. (1998). Reciprocal suppression of regional cerebral blood flow during emotional versus higher cognitive processes: Implications for interactions between emotion and cognition. Cognition and Emotion, 12(3), 353-385.

Gile, D. (1995). Basic concepts and models for interpreter and translator training. Amsterdam: John Benjamins Publishing Company.

Jensen, E. (1998). Teaching with the brain in mind. Alexandria: ASCD.

Jensen, E. (2000). Brain-based learning. San Diego: The Brain Store.

Katrancı, M. ve Yangın, B. (2013). Üstbiliş stratejileri öğretiminin dỉnlediğıni anlama becerisine ve dinlemeye yönelik tutuma etkisi. Adıyaman Üniversitesi Sosyal Bilimler Enstitüsü Dergisi Türkçenin Eğitimi Öğretimi Özel Sayısı, 11, 733-771.

Lupien, S. J., Wilkinson, C. W., Briere, S., Menard, C., Ng Ying Kin, N. M. K., ve Nair, N. P. V. (2002). The modulatory effects of corticosteroids on cognition: Studies in young human populations. Psychoneuroendocrinology, 27(3), 401-416.

Madigan, R. (2015). How memory works and how to make it work for you. [Bellek nasıl çalışır: Belleğinizi değerlendirmenin yolları. Y. Yemenici \& A. Yemenici, Çev.]. New York: The Guilford Press.

McCraty, R., ve Childre, D. (2003). The appreciative heart: The psychophysiology of positive emotions and optimal functioning. Boulder Creek, CA: Institute of HeartMath.

McCraty, R., ve Childre, D. (2004). The grateful heart: The psychophysiology of appreciation.In R. A. Emmons ve M. E. McCullough (Eds.), The psychology of gratitude ss. 230-255. New York: Oxford University Press.

Morgan, C. T. (2004). Psikolojiye giriş. Ankara: Hacettepe Üniversitesi Psikoloji Bölümü Yayınları.

Morris, C. G. ve Maisto, A. A. (2002). Psychology: An introduction. Prentice Hall College.

Olff, M., Brosschot, J. F., ve Godaert, G. (1993). Coping styles and health. Perspectives on Individual Differences, 15(1), 81-90.

Reiche, E.M., Nunes, S.O. ve Morimoto, H.K. (2004) Stress, depression, the immune system, and cancer. Lancet Oncology, 5(10), 617-625.

Roche, N. (1999). Roche on notes: Note-taking for consecutive interpretation [Video file]. Retrieved from https://www.youtube.com/watch?v=1Z-AmvDMDN8

Sapolsky, R. M. (2004). Why zebras don't get ulcers? NY: Holt Paperbacks.

Seligman, M. (1992). Helplessness. New York: W. H. Freeman.

Terry, W. S. (2006). Learning and memory: Basic principles, processes, and procedures. New York: Pearson.

Treisman, A. M. (1964). Verbal cues, language and meaning in selective attention. American Journal of Psychology, 77, 206-219.

Veenman, M. V. J., Hout-Wolters, B. H. A. ve Afflerbach, P. (2006). Metacognition and learning: Conceptual and methodological considerations. Metacognition and Learning, 1, 3-14.

Vincent, J.D. (1990). The biology of emotions. Cambridge, MA: Basil Blackwell.

Wolfe, P. (2001). Brain matters: Translating research into classroom practice. Virginia, USA: ASCD.

Yalçın, P. (2003). Çeviri dersinde öğrencilerin karşılaştıkları belli başlı problemler. Türk Eğitim Bilimleri Dergisi, 1(4), 463-469. 